\title{
The Second Language Acquisition by Mixed Marriage Child (A Study Case)
}

\author{
Luh Ann Pulsa \\ English Department, Faculty of Arts, Udayana University \\ [luhannpulsa@gmail.com] \\ *Corresponding Author
}

\begin{abstract}
Unlike a general family, mixed marriage child has to learn other language starting from young age, or can be said as a bilingual child. He or she will learn their second language either his mother's language or father's language. The aims of this study are to find out the type of second language acquisition by the mixed marriage child and to find out the influencing factor for the child to acquire their second language. Three methods and technique are used in this study, the first is method and technique of collecting data using interview and recording methods in order to collect the data; the second is method and technique of analyzing data, qualitative method is used in this part by using three theories proposed by Ellis, Krashen Berry and Einsenson; and the third is method and technique of presenting data using informal method. The result of the study is Henry as mixed marriage child has naturalistic type who acquires the language by communicating with his family and surrounding directly. There are five factors influencing his second language acquisition; they are physiological condition and motor ability, intelligence, economic status, sex, and environment.
\end{abstract}

Keywords: second language acquisition, mixed marriage child, language types.

\begin{abstract}
Abstrak
Berbeda dengan keluarga pada umumnya, anak dari keluarga perkawinan campuran harus belajar bahasa lain sejak dini, atau bisa disebut sebagai anak bilingual. Dia dapat belajar bahasa keduanya baik bahasa ibunya maupun bahasa ayahnya. Tujuan dari penulisan ini adalah menemukan tipe pemerolehan bahasa kedua pada anak perkawinan campuran dan faktor - faktor yang mempengaruhi pemerolehan bahasanya. Ada tiga metode dan teknik yang digunakan, pertama metode dan teknik pemerolehan data menggunakan metode dan teknik wawancara dan obeservasi; kedua metode dan teknik analisis data menggunakn metode kualitatif yang mana data dianalisis menggunakan teori - teori dari Ellis, Krashen, dan Berry dan Einsenson; dan untuk penyajian data menggunakan metode informal. Hasil yang didapat dari penelitian ini adalah Henry yang seorang anak perkawinan campuran memiliki tipe natural yakni memperoleh bahasa keduanya melalui komunikasi antar keluarganya dan ada lima faktor yang mempengaruhi yakni kondidi psikologi dan kemampuan motorik, kecerdasan, status ekonomi, jenis kelamin, dan lingkungan.
\end{abstract}

Kata kunci: pemerolehan bahasa kedua, anak perkawinan campuran, tipe bahasa.

\section{Background of the Study}

Some people say that in learning languages children are faster to learn new languages then adults. They said that children easily gain new languages effortlessly. Perhaps this has something to do with the plasticity of the brain.
According to Pinker, acquisition is guaranteed for children up to the age of six until shortly after puberty, and is rare thereafter' (Pinker 1994: 43), and that this applies not only to the acquisition of the first language, but also to the second or foreign language. 
Mixed marriages become the most common phenomenon in recent days. Those who do mixed marriages have accepted and understood each culture that they bring, as well as their native language. The children whose parents speak different languages, for example, English and Bahasa Indonesia, depend on the parents who teach the language. If the children are accustomed using one of parents' language, they lead to use one of those languages. Hauwaert (2011) stated "having parents who speak different languages is often seen as a gift for children, who will naturally pick up both languages." However, the difference of parents' languages will influence the children in acquiring the language. The children will try to express what they mean by using the words that they have heard. Therefore, it is necessary for children to learn both languages to communicate with their parents well.

There are a lot of causes making the children either they are bilingual at the beginning or have their second language because of their mixed marriage parents. It depends on the situation of the children such as the environment, intelligence of the children, and other factors that perhaps can influence. This background brings up the issue and questions, so that this study examines the second language of mixed marriage child which is really interesting to investigate deeper.

\section{Problem of the Study}

a) What is the type of second language acquisition obtained by the mixed marriage child?

b) What are the factors influencing the child (Henry) in acquiring their second language?

\section{Aims of the Study}

a) To find out the type of second language acquisition by the mixed marriage child. b) To analyze the factor influencing the child in acquiring their second language.

\section{Research Method}

Methodology can be defined as procedure used to require the data in doing the research. Methodology is also used as the way or the steps in order to analyze the topic which is discussed in the study and used to solve the problems to produce a scientific study. The research method that will be discussed in this study includes the data source, method and technique of collecting data, and method and technique of analyzing data.

\subsection{Data Source}

The data were obtained from mixed marriage child. The child is Hendry Suryawan. He is 4 years old. His parents are Komang Ari Suryawan and Cherie Suryawan. His father's nationality is Indonesia, while his mother is Australian. They stay in Australia, Melbourne, because their parents work there. However, every July or August they are back to his father's home, Bali, in order to meet their family who live in Padang Bai, Karangasem, either to pray or gather with their family.

\subsection{Method and Technique of Collecting Data}

The data were obtained through direct interaction and conversation with the child to his family in daily life when they were in Bali. The technique used in collecting the data was by note taking and recording (video). While the mixed marriage child doing his daily activities at his home or surrounding, he was recorded by electronic tool (camera or hand phone). The information that was obtained from observing the child directly was recorded. Thus, the techniques are examined as the following steps: interviewing by giving questions 
addressed to the parents and relatives; observing and recording the children daily activity; and taking some note.

\subsection{Method and Technique of Analyzing Data}

In order to analyze the data, this study used qualitative method. The data were analyzed using the theory proposed by Ellis (1986) and supported by Krashen's hypothesis theory (1982) in analyzing the type of acquiring the second language; and the influencing factors of child's language acquisition proposed by Berry and Einsenson (1973).

\subsection{Method and Technique of Presenting Analysis}

According to Sudaryanto (1993:145), this study used informal method to present the data written descriptively so that the data could be understood easily and clearly. First, the study examined the type of second language acquisition by mixed marriage child. Second, the study examined the influencing factors of mixed marriage child's second language.

\section{Result and Discussion}

The results and discussions of this study are divided into the type of second language acquisition and influencing factor.

\subsection{The Type of Second Language Acquisition by Mixed Marriage Child}

According to Ellis, second language acquisition can be said as subconscious or conscious process by which a language orders than mother tongue was learnt in natural or a tutored setting development of phonology, lexis, grammar, and pragmatic knowledge. $\mathrm{He}$ also proposed two types of second language acquisition, naturalistic and formal.
After observing the object of the study, which was a mixed marriage child, Henry tended to have the first type which was naturalistic type. Henry did not acquire Bahasa Indonesia as his second language through guidance by teachers, tutors, or other materials from any sources. He acquired Bahasa Indonesia unconsciously when he communicated with his family.

As Krashen's theory of ways in acquiring second language, Henry tended to gain his second language through subconscious acquisition. Subconscious acquisition means the speaker communicates his second language focusing in meaning and purpose. Therefore, when Henry communicated with his family in Bali, he spoke without thinking the form but the meaning

\subsection{Krashen's Hypothesis in Acquiring Second Language Acquisition}

As well as Krashen's hypothesis theory, there are several hypotheses which support this analysis:

1) The Acquisition-Learning Hypothesis

Krashen stated that there are two ways to obtain second language; acquisition and learning. He said that acquisition refers to the process which is developed by the child unconsciously. As already explained, Henry obtained his second language unconsciously which means that he acquired the language without realizing or being aware of the action, this process is developed the same as he obtained his first language.

2) The Natural Order Hypothesis According to the definition of natural order hypothesis, Krasen stated that all language learners of any single second language appear to follow the same 
predictable order; for example, English learners generally acquired the grammatical yesno questions before the grammatical structure $w h$ questions. In the interview, Henry's father also said that Henry acquired yes- no question at first. Probably the reason was that yes-no question was the easiest to acquire because the words were easy to remember, in addition it was factious if adults gave difficult questions which had long answer to answer.

3) The Monitor Hypothesis

According to Henry's situation, he tended to speak as it was without thinking the role the meaning which was delivered. Besides, he did not learn the rule of Bahasa Indonesia formally; in Bahasa Indonesia, its grammar was not too complex. In Bahasa Indonesia, as long as the speaker and his partner understand the meaning that could not be a problem. Therefore, Henry was a under - user which those learners who have not learned or who prefer not to use their conscious knowledge.

4) The Input Hypothesis

In this hypothesis, Krashen said that the acquirer does not gain the second language if he or she does not understand the meaning. In his second language, Henry did not understand all sentences in his conversation with his aunt. Therefore, he only acquired several words.

5) The Effective Filter Hypothesis In Henry's case, his family makes efforts to motivate him to speak in Bahasa Indonesia. His father in every occasion helps him acquire more Bahasa Indonesia vocabulary; it seems that Henry enjoyed his process of learning new language. The motivation of Henry to learn second language came out from his family, although there was no seen motivation from Henry (the individual), he kept learning Bahasa Indonesia with fun. This is the process of Henry in this hypothesis; and can be concluded that it is extrinsic motivation because it is affected by Henry's family.

\subsection{The Influencing Factors of Children's Language}

In acquiring a language, there are several factors that influence to acquire the language. According to Berry and Einsenson (1973), there are six factors influencing to acquire a language. After observing Henry in a week, he acquired his second language because there are some factors influencing him. Those factors are explained as follows:

\subsubsection{Physiological Condition and Motor Ability}

During observation, Henry was a cheerful, active, energetic, and healthy child. His condition helped him gain more vocabulary because there would not be an obstruction, and then it was more possible to gain new words. Not only his father, other relatives helped him speak Bahasa Indonesia by having communication with him intensively. Therefore, he could learn Bahasa Indonesia without pressure.

\subsubsection{Intelligence}

Henry has capability of memorizing, although he could not create good sentences. As long as he understood what others were saying, he could reply with simple answer. Hendry do not have intelligence test yet; therefore, it was difficult to decide either Henry has 
superior intelligence or normal intelligence.

\subsubsection{Economic Status}

Economic status of Henry's parents can be said at middle class; neither are they wealthy nor poor family. The job of Ary Suryawan as farmer was good enough to suffice their needs even they could fund the trip either when they were going to Bali or return home. It showed that economic background of Henry's family was capable to have more conversation in Bahasa Indonesia, it may also his economic status was not an obstruction to acquire more vocabulary of Bahasa Indonesia.

\subsubsection{Sex}

During observation, Henry spoke either in English or in Bahasa Indonesia; he tended not to speak too much, yet he played more. He would speak in Bahasa Indonesia if his family spoke in Bahasa Indonesia as well, and then spoke in English as the language when he spoke either with his mother, his brother, or the sentences that he did not know. The factor of the sex could influernce how Henry acquired his second language.

\subsubsection{Environment}

According to Berry and Einsenson, children's language was influenced by the environment as well. He claimed that mother-child relationship was the prominent of the child to acquire the language. Henry was close enough to his mother than his father so that his first language was English; besides, he lives with the people who English as their language. However, his father who speaks Bahasa Indonesia as his first language wanted his son to speak the same language as he did. Then at the $4^{\text {th }}$ age of Henry, his father started to transmit Bahasa Indonesia to him after he could speak English well. Because
Henry's family goes to Bali routinely which is every year, his second language would develop gradually. Indeed, his relatives who stayed in Bali helped him gain more vocabulary and create sentences because his relatives rarely spoke English to him, they would speak Bahasa Indonesia either he understood or not, then this situation forced him to learn Bahasa Indonesia no matter how.

\section{Conclusion}

Based on the analysis and discussion above, the following points can be the conclusions:

Henry is a mixed marriage child who acquired Bahasa Indonesia with natural system. It meant he was a naturalistic type in acquiring his second language accordance to Ellis theory. In addition, theory hypothesis by Krashen helped to analyze the way of the child acquired the language and to support Ellis's theory that Henry acquired his second language by natural way not formal way which meant without tutors and teachers. He obtained his second language with genuine through communication with his father's family and especially with his father which was Bahasa Indonesia as his native language. Although Henry lives in Australia, do not mean his second language was never uttered, Bahasa Indonesia would be spoken when he talked with his father and father's relatives who stayed in Bali. Routinely every year in a month, this mixed marriage family would back to Bali; and this was Henry's opportunity to speak and learn Bahasa Indonesia much more. In addition, English is main language of Henry's daily communication, whereas Bahasa Indonesia is optional language when he talked to his Balinese relative and his father at timesHenry's second language acquisition was inseparable from the influencing factors. There were 
six factors proposed by Berry and Einsenson but only five factors that influenced his second language such as physiological condition and motor ability, intelligence, economic status, sex, and environment.

\section{References}

Berry, M. F \& Eisenson J, (1973).Speech Disorder Principles and Practice of Theory. USA: Appleton-CenturyCrofts, Inc.

Ellis, R. (1994). The Study of Second Language Acquisition. Oxford: Oxford University Press.

Hauwaert, S. B. 2011. Bilingual Parenting: OPOL or Mixed Language-Does it Matter?,Available from URL: http://www.incultureparent.com/aut hor/suzanne-barronhauwaert/Retrieved: May, 222017.

Krashen, S. D. (1982). Principles and Practice in Second Language Acquisition. Oxford: Pergamon.

Pinker, Steven. (1994). The Language Instinct: How the Mind Creates Language. William Morrowand Company.

Skinner, B. F. (1957). Verbal Behavior. Copley Publishing Group.

Sudaryanto. (1993). Metode dan Aneka Teknik Analisis Bahasa: Pengantar Penelitian Wahana Kebudayaan secara Linguistis. Yogyakarta: Duta Wacana University Press. 